\title{
A MONASTIC MANUSCRIPT PARALLEL TO THE PARNASSUS MUSICUS FERDINANDAEUS
}

\author{
RUDOLF FLOTZINGER \\ Graz
}

Izvleček: Med vsebino in okoliščinami tiskane antologije Parnassus musicus Ferdinandaeus, ki je bila leta 1615 posvečena notranjeavstrijskemu vladarju v Gradcu, in rokopisno zbirko, ki je bila okoli leta 1625 pripravljena za rabo menihov v samostanu Kremsmünster (Ms. L76), je veliko paralel. Obe odsevata zgodnje širjenje repertoarja in sloga italijanske duhovne monodije $v$ avstrijskih deželah, ki ga deloma lahko pripisujemo tudi osebnim stikom med domačimi glasbeniki in njihovimi italijanskimi vrstniki.

Ključne besede: italijanska glasba, mali duhovni motet, Avstrija, glasbeni rokopis A-KR, L76, Parnassus musicus Ferdinandaeus, glasbeni kontekst.

\begin{abstract}
There are many parallels in the context and content of the printed anthology Parnassus Musicus Ferdinandaeus, dedicated in 1615 to the Inner-Austrian ruler in Graz, and the manuscript collection assembled around 1625 for the use of the monks at the Kremsmünster monastery (Ms L76). They reflect alike the early diffusion of the Italian sacred monodic repertoire and style in regions of Austria, thanks partly to personal contact between native-born musicians and their Italian contemporaries.
\end{abstract}

Keywords: Italian music, the small-scale motet, Austria, music manuscript A-KR, L76, Parnassus Musicus Ferdinandaeus, musical context.

The core subject of the conference Parnassus Musicus Ferdinandaeus (1615) of 2015 was a music print from a courtly environment taken as a characteristic exemplar for the dissemination of Italian music in Europe. Closely related to this publication is the legendary marriage strategy of the Habsburg family, which involved various European musical centres: from Naples up to Venice and from there outlining a wide arc of courts already (or soon to be) refashioned on Italian lines stretching from Graz via Cracow to Alba Julia north of the Alps. Also requiring inclusion are ecclesiastical centres such as the residence of the bishop of Breslau (i. e., the former Archduke) Karl (1590-1624) in Neisse (Silesia) and that of bishop Leopold (1586-1632) in Strasbourg (Zabern in Alsace) and Passau. If musical criteria were to be foregrounded, other centres, too, would be worth a mention: at the very least, Salzburg under archbishop Marcus Sitticus von Hohenems (1612-1619) and probably also Gurk under prince-bishop Johann Jakob von Lamberg (1603-1630) in Straßburg (Carinthia).

It is obvious that governments, especially when in flux, were always open to new ideas, to other persons and things: in short, to so-called cultural transfer. And of course 
one should never overlook the contemporary political situations, the actual meanings of words and even the lack of modern terms and the concomitant problem of projection: for example, whenever concepts such as state, border, region, identification, language and mentality are employed. It is also evident that each strand belonging to such a transfer stands for many, if not innumerable, constituents of "pathways" that would finally create networks but only rarely led in a single direction.

Certainly, all these aspects of modern historiography are visible when one uses the Parnassus as an example. In this connection, I wish to draw attention to a different network, one at least as successful as that of family connections and literally "operational" since the early Middle Ages in fields such as music: namely, that present within the Christian church, for example between religious orders and their monasteries. I cannot reveal any hitherto unknown sources, but I shall suggest an interpretation under the general rubric of cultural transfer. I leave out of consideration the Parnassus Musicus Ferdinandaeus anthology as such, noting only the fact that it was not quite the first representative of its genre to appear in Graz, and I will similarly pass over its direct forerunners, such as Bartolomeo Mutis de Cesana's Musiche a una, doi e tre voci (Venice, 1613) and Heinrich Pfendner's Delli motetti (Graz, 1614). ${ }^{1}$

Already half a century ago in my typescript dissertation, ${ }^{2}$ and subsequently in a separate publication, I offered up for discussion two small manuscripts written out around 1625 by a presumably clerical Italian scribe and today preserved in the music library of the Benedictine Abbey of Kremsmünster ${ }^{3}$ in Upper Austria. One (shelfmark L64) is a collection of parts for various sacred and secular musical works; the other (shelfmark L76) is a more distinctive music manuscript containing 39 compositions, mostly motets for a few voices with basso continuo (the list of composers is provided in table 1). This homogeneity makes the second manuscript directly comparable with the printed Parnassus Musicus Ferdinandaeus from 1615 (see also table 2). How and when both manuscripts came to Kremsmünster is not known precisely. I will revisit my earlier arguments and conclusions in the hope of adding to their solidity.

Nearly every year during the period when father Wolfgang Christan (d. 1625) was regens chori there one or more new compositions were bought for the Kremsmünster music library. In 1632/33 father Christan's successor, father Benedict Lechler (d. 1659), together with a fellow monk, made a trip to Italy (Venice, Rome, Naples) to visit the mother house of Monte Casino in order to study there all kinds of "modern" church music. From this trip Lechner brought home (as can be proved) a manuscript containing falsobordone settings, together with some newly published Venetian collections by Laurentio Ratti (1628), Giacomo Finetti, Pietro Francesco Garzi and Alessandro Grandi (all 1629) and, finally, Stefano Bernardi (1632). Between 1633 and 1649 Lechler entered further material of a similar kind into his five manuscript volumes housing, in the form of scores (less

1 For more on these collections see Federhofer, Musikpflege and Saunders, Cross, Sword, and Lyre.

2 Flotzinger, "Die Lautentabulaturen des Stiftes Kremsmünster".

3 Benediktinerstift, Musikarchiv, Kremsmünster, L76. See also Flotzinger, Eine Quelle italienischer Frühmonodie. 
common at the time than partbooks), a variety of contemporary sacred compositions, some requiring many voices and instruments and multiple cori, and many of them by Italians. In alphabetical order, these authors were Giacomo Carissimi, Antonio Cifra, Alessandro Grandi, Lorenzo Ratti, Teodoro Riccio and Giovanni Sansoni. Lechner had met Carissimi and Ratti personally while staying in Rome at the Collegium Germanicum, and this surely incomplete roster of composers mirrors his itinerary exactly.

Lechler, who was born in 1594 in Füssen and from 1607 to 1615 studied at the imperial college in Vienna, repeated, over twenty years later, an experience that Heinrich Schütz (1585-1672) had enjoyed in Venice around 1610: he became one of those musicians from north of the Alps who, aided by a bursary or at least by leave of absence from their employers, were able to travel to Italy for the purpose of musical study and/or the collection of material. At first glance, it appears not improbable that Lechler brought back the manuscripts L64 and L76, together with a few others, in 1633. This allows the possibility that their works were at least some years older.

Another group of composers represented in Lechler's manuscripts consists of Italian composers formerly or at that time active in Vienna (the same names recur in Bonometti's print): Giovanni Priuli, Giovanni Sansoni, Alessandro Tadei, Giovanni Valentini and Pietro Verdina. It is striking that Lechler wrote out only one motet (Hodie Maria virgo) by Tadei (c. 1585-1667), and that this occurred only in his last manuscript (post-1649). Tadei, presumed to have been a native of Graz and a pupil of Giovanni Gabrieli (1557-1613), became a court organist in Graz and Vienna - but in 1628/29 he also served for half a year as [saecularis] musicae praefectus in Kremsmünster during the period when Lechler was regens chori [ecclesiastici] there. ${ }^{4}$

The external, visible differences between the printed and manuscript collections under discussion (the Parnassus and L76) are of less interest than the internal differences - or similarities - between their respective compositions. In both instances, the intention - leaving aside the possible role of the compositions as models for imitation by native musicians - was to obtain new, up-to-date ecclesiastical compositions for the liturgy. In this regard, there is no major divergence between the perspectives of secular and religious courts and monasteries from that time. Quite the reverse is true: it is astonishing how quickly church music absorbed and adopted an altogether nova maniera (to use the words of the Florence singer-composer Giulio Caccini in the foreword to his Nuove musiche of 1601). In its common modern definition this maniera is characterized by its practice of "imitating the theatrical exaggeration of affective Italian speech", an imitation that also calls for a new mode of singing.

Although this question does not stand here in the foreground, one has also to take account, when looking for influences beyond the avowedly secular theatrical genre, of the Cento concerti ecclesiastici (1602) by the Franciscan friar Ludovico Viadana from Mantua. These two publications represent two positions in a certain movement directed

4 Kellner, "P. Benedikt Lechler". Excerpts from his dissertation were published in Jahresberichte des Obergymnasiums der Benediktiner zu Kremsmünster (1933-1936) under the title "P. Benedikt Lechler. Ein Meister der Musik aus der Zeit des Dreißigjährigen Krieges”. 
against the traditional polyphony of that time by reducing the number of voices and combining them with a basso continuo to produce the sacred concerto style and monody. ${ }^{5}$

These divergent polarities in the Parnassus and our manuscript L76 actually appear as complementary, and that in several aspects: concerning their provenance and destination (court / monastery), their content (theatrical vs. clerical, more ostentatious vs. simple) and their performance and practicability - one to five vocal parts with basso continuo in the one vs. only one or two voices in the other. The latter option is also much easier to accommodate in relatively indigent and small institutions. This fact obviously corresponds not by chance to the clerical tradition of Viadana; nevertheless, Caccini's and Viadana's publications shared a high, almost identical, reputation: that of being the most up-to-date. Therefore, the fact that Viadana was a Franciscan friar (a so-called Mendicant) is of importance for our present-day understanding because it unites the modesty of those orders (practised not only by the Mendicants but also, for example, in the proverbial Franciscan Mass) with the reputation of the sacred concerto and monody, which was inspired by the brand-new theatrical genres (namely, rappresentazione, opera and oratorio). But while the reality of practical performance brings out striking differences between these compositions, their styles are far from being reducible to the mere rejection of polyphony employing several voices. They at least offer further possibilities of differentiation of performance (including differences in compositional technique), but polyphony was not banished at all.

Nearly half of the content of Bonometti's printed collection published in Venice by Vincenti comes from only nine of his former colleagues (representing 15\% of the 32 coeval composers) at the Graz court (see also table 2). ${ }^{6}$ Among them Giovanni Priuli (c. 1575/80-1626), the probably Venetian-born Kapellmeister in Graz and, after 1619, Vienna, who is represented by four motets, ranks comparatively highly, falling just short of the five by his only slightly junior organist, later to become his successor as Kapellmeister, Giovanni Valentini (c. 1582/83-1649). Priuli, with three motets, is the only Graz-related composer also to be found in manuscript L76 (the full list of composers is given in table 1). Here, Priuli's motets appear alongside the one motet each composed by Federico Coda (?-?) ${ }^{7}$ and Giacomo Filippo Bium(i)o (c. 1580-1653), who around 1625 were both organists in or in the vicinity of Milan; ${ }^{8}$ all three composers have just one, identical piece reproduced in the Parnassus.

These facts seem at first glance to have relevance for the musical knowledge of the copyist of the manuscript as well as for that of the editor Bonometti, since both men gravitate in their choices towards the region stretching from Milan to Venice. This consideration could also be of some importance, since Tadei, during his already mentioned activity in Kremsmünster, published in 1628 at Venice (with Magni) his Psalmi vespertini [...] octo vocibus, ${ }^{9}$ which he dedicated to abbot Anton Wolfradt (1581-1639), who at that time was

5 Flotzinger, "Die kirchliche Monodie".

6 Federhofer, "Graz Court Musicians".

7 Federicus Cauda was in 1626 Musicae praefectus in Ecclesia Cathedrali Cinitatis Derthonae Status Mediolani.

8 Flores praestantissimorum virorum. "Musicorum nomina".

9 Kellner, Musikgeschichte, 197. 
also Hofkammerpräsident at the Viennese court and afterwards was very active in several other imperial roles. ${ }^{10}$ On the title page of the Psalmi Tadei is styled " $\mathrm{R}$ [everendus] D[ominus]". This tells us that he had already by then (following the death of his wife) become a monk: it has been established that he became a member of the Carmelite order, another mendicant one, only in $1640 .{ }^{11}$ In that light, it is not wholly improbable that our manuscripts came to Kremsmünster via Tadei.

The two manuscripts L64 and 76 differ in the already mentioned formal respects but are nevertheless both very likely of religious origin. The 39 settings (mostly motets) in L76 are more or less intended for liturgical use: 12 for the Office, 4 for the Mass; the remainder have texts taken from Scripture (psalms, the Song of Songs) or devotional poetry, all being closely connected with monastic life (with themes including Christmas, Mother Mary, the Guardian Angel, the Holy Trinity and the Passion). They could have found a use mainly in Vesper services, in which Lechler showed particular interest. ${ }^{12}$ The content of the sister manuscript L64 is not unified to the same extent, since it clearly divides into four somewhat related parts:

1) texts taken from hymns and also the Song of Songs,

2) excerpts from Girolamo Diruta's textbook Il Transilvano, vol. 2 (1609/25) concerning matters such as the intabulation of music for the lute,

3) 18 pieces in Italian lute tablature,

4) 45 French and Spanish airs with lute accompaniment. ${ }^{13}$

These items must have been no less interesting for Lechler, since from 1617 onwards, ten years before himself becoming a (Benedictine) monk, he had served in Kremsmünster as an "officer" and "Ir Gnaden Laudanist" (the abbot's lutenist). ${ }^{14}$ The author Diruta (1554/64-1610) was a Franciscan friar and had written his two-part textbook Il Transilvano while studying in Venice with Gioseffo Zarlino, Costanzo Porta (both likewise Franciscan friars) and Claudio Merulo. ${ }^{15}$ The title of the book refers to the dedication of its first volume to Prince Zsigmond Báthory (1572-1613), husband of Archduke Ferdinand's sister Maria Christina (in sources also Christierna) and regent of Transylvania between 1588 and 1598. Additionally, after the change in the political situation the posthumous reprint of $I l$ Transilvano in 1625 made the book again in a certain sense topical. Certainly, all of this fits in well with several of the points mentioned earlier, but it ultimately tells us no more about the exact provenance of our manuscripts.

A striking point is that in both L64 and 76 the Florentine singer Caccini (c. 1550-1618) plays a certain role as a composer: while in the secular manuscript L64 several madrigals from his Nuove musiche (1601) are merely quoted (not notated), in the sacred collection L76 (for a maximum of two singers) we find - much more surprisingly - under the not

${ }^{10}$ Kellner, Profeßbuch des Stiftes Kremsmünster, 205-207.

${ }^{11}$ Federhofer, "Alessandro Tadei”, 115-131; Federhofer, Musikpflege, 216-218.

${ }^{12}$ Kellner, Musikgeschichte, 201.

${ }^{13}$ Most by Gabriel Bataille (c. 1575-1630); Flotzinger, Die Lautentabulaturen des Stiftes Kremsmünster, 17-18, 57-72 and 269-270.

${ }^{14}$ Kellner, Musikgeschichte, 195; Kellner, Profeßbuch des Stiftes Kremsmünster, 213.

${ }^{15}$ Navach, "Diruta". 
uncommon name "Giulio Romano" (the surname denoting the city of birth) - two contrafacta (love songs from the Nuove musiche in which new texts have been underlaid to the music, thereby transforming them in a single two-part Passion motet, Movetevi a pieta / $O$ domine Jesu + Queste lagrime amare / Mors enim tua).${ }^{16}$

In the same manuscript, in a similar way, Viadana (1564-1627) appears not only as the composer of the two anonymous numbers - 10 (Bonum est confiteri Domino) and 36 (Congratulamini mihi omnes) - but also of a third one for Basso solo, which is merely a reduced version of a four-voice motet: 16 (Cantate Domino canticum novum); all of them come from the Cento concerti ecclesiastici (several prints between 1602 and 1612).

The composer most strongly represented in L76 is Antonio Cifra (1584-1629), who in fact is one of the most successful users of concerto style and monody, whereas other pieces in this manuscript (for example, those by Biumi and Coda) merely experiment with the adaptation of traditional motets. Cifra was resident in the Papal State not only as a representative composer in the new styles but also as one of the earliest, which shows that these styles had arrived there quite early on and were openly nurtured. This matches well the fact that Cifra changed post in Rome several times (Collegium Germanicum, San Giovanni in Laterano) and also worked in Loreto (Santa Casa), at that time the most important place of pilgrimage. Loreto was not placed under the management of mendicant friars but was controlled by the newly established Jesuit order, which only later discovered music as useful for its interests. But from its beginnings, this order has to be viewed in close connection with the so-called Counter-Reformation, just as, for their part, the new styles, both musical and visual (baroque), were linked to the Council of Trent, which took place in the mid-sixteenth century. ${ }^{17}$

Altogether, the dates and provenance of the Kremsmünster manuscripts have become at best a little clearer, but are still far from precise. The one essential fact is that their copyist must have been a professional musician with a specific interest in "modern" church music. This unmistakably emerges in L76 from the contrafacta (probably the composer's own) of songs by Caccini (Florence), the partly arranged pieces by Viadana (Mantua) and the settings by their successor Cifra (Rome). The adaptations provide clear evidence that this collector worked for himself or for usage within his house (monastery).

On the other hand, the copyist's inclusion of individual motets by Claudio Monteverdi (1567-1643) and Priuli could have been inspired by their connection with Venice as well as by their fame: Monteverdi may have been included simply by virtue of being a leading composer of the time, while Priuli may have qualified as a kind of specialist (at least in the collector's eyes). This must also be the reason why Priuli, not Cifra, is the sole composer from the group of Graz musicians to be present both in the Parnassus and in L76. But to continue: the solitary examples in L76 by Biumi and Coda (both from Milan) and Turini (born in Prague, but from 1624 onwards organist at Brescia cathedral) all conform to the regional connection leading from Milan to Venice.

Indeed, only one name appears at present to be anomalous: that of Daniel Bollius

${ }^{16}$ Flotzinger, Eine Quelle italienischer Frühmonodie, 20 and 23; Flotzinger, "Die kirchliche Monodie“, 78-79.

${ }^{17}$ Flotzinger, "Die kirchliche Monodie", 79. 
(Bolle? c. 1590-c. 1638), who was born in Württemberg and from 1626 worked as the organist (and later the Kapellmeister) of Archbishop Johann Schweikard von Kronberg in Mainz (1553-1626). ${ }^{18}$ Only when we learn that he was "one of the earliest exponents in Germany of the Italian oratorio form" and that he in any case had a specific "interest in the Italian ornamental style of singing" are we able to recognize him as a musician coming from the "other" (north-south) axis - i. e., as an early German student of, or in, Italy (by what route is unknown, in contrast to Heinrich Pfendner and Vincenc Jelich with their Graz connections, for instance). Bollius's Repraesentatio harmoniaca [...] Sancti Joannis (1619/25) could well be older than the Historia der [...] Auferstehung by Schütz (1623), and its composer might be seen as a Catholic counterpart to the Protestant Schütz in the role of a German intermediary to the north. Therefore, we can easily imagine that a well-informed Italian knew of him and admitted him to his collection.

This, then, not only fits in to, but matches perfectly, the diversity that the scribe of our manuscript displays by indirectly referencing not only Italian cities stretching from Rome, via Florence, Mantua, Milan and Brescia, to Venice, but also northerly Mainz. This diversity cements the impression that he must have been a genuine specialist. His biases and actions reveal basic differences from those of the editor Bonometti, who was not himself a composer. On account of the chronological gap of approximately ten years between the two motet collections, Parnassus and L76, the former naturally comes into question as a source for one piece or another in the latter, but there is no stronger evidence of direct transmission. All the compositions must have been well known to a potential user, and the collections were very likely made independently of each other. Matching the selection principles of the two collectors, as these have come to light after careful study, the liturgical aims of the musical material presented are comparably diverse. The music was usable not only within a normal liturgical framework but also for private devotions at a court (secular or religious).

These comparisons afford good insights into the problem of artistic transfer. It is clearly no devaluation to view the Parnassus under two aspects:

1) as an transfer into a new environment of pieces by the Archduke (later Emperor) Ferdinand's own musicians by contemporaries then still living in Italy, and

2 ) in the light of the rising number of voices, a factor also introducing stylistic differentiation.

Only at a first glance (and only then, not surprisingly) has the impression emerged that the contents of L76 on the one hand and of the Parnassus excluding the Graz musicians on the other hand seem to refer to the same region of origin (Milan-Venice), whereas they have ended up appearing quite different in respect of the capacities and aims of the two collectors. But the most important difference between the two collections is that the Parnassus demonstrates normality, insofar as movements of persons represent the most successful carrier (media) for cultural transfer, whereas manuscripts are always tools in those persons' hands: they have already worked for a longer time.

If I therefore had also included in my survey other prints dedicated to Archduke Ferdinand, such as Mutis di Cesana's Musiche a una, doi e tre voci (1613), Pfendner's

${ }^{18}$ Kirwan and Johnston, "Bollius". 
Delli motetti (1614) and Vincenc Jelich's Arion primus and Arion secundus (1628), several details would have been added: Cesana (c. 1575/80-1623) was a singer and chaplain in Graz; Pfendner (c. 1588-1630) was a pupil of Cifra in Rome and around 1615 for some time an organist in Gurk and Graz; Jelich (1596-1636) studied with Matthias Ferrabosco (1550-1616) in Graz and in 1617 was summoned to Zabern by Archduke Leopold. ${ }^{19}$

These aspects confirm the importance of the Graz court, but they would have progressively deflected our interest from the central question of the dissemination of Italian music. The reason is that data supporting the comparison had to be assumed in advance. Such facts can always bring to light more interesting details that have nothing to do with the original topic, ${ }^{20}$ since cultural transfer is not a method but a special question ("special" always means in addition "narrow"). Remember, for instance, that after the Council of Trent monasteries acquired important responsibilities with regard to music on account of the papal instruction that they should in future use chant books following the Roman liturgy and should embrace and disseminate new forms of church music. Only a considerable time later did musicologists recognize how closely bound up with these institutions most of the innovations that we classify under the term "baroque" - even including the completely new musico-dramatic and instrumental genres - actually were. But that is another story.

\section{Table 1}

Composers in Ms Kremsmünster L76

\begin{tabular}{|l|}
\hline Biumi (Jacomo Filippo, c. 1580-1653) \\
\hline Bollius (Daniel, c. 1590-c. 1642) \\
\hline Caccini (Giulio, c. 1550-1618) \\
\hline Cifra (Antonio, 1584-1629) \\
\hline Coda (Federico, ?-?) \\
\hline Monteverdi (Claudio, 1567-1643) \\
\hline Priuli (Giovanni, c. 1575-1629) \\
\hline Scaleta (Orazio, c. 1560-1630) \\
\hline Turini (Francesco, $c .1589-1656)$ \\
\hline Viadana (Ludovico, 1564-1627) \\
\hline
\end{tabular}

${ }^{19}$ See the relevant articles by Wolfgang Suppan in the Steirisches Musiklexikon.

${ }^{20}$ For instance, the fact that Lechler around the same time (1628) became a priest, which could have been a reason why Tadei left Kremsmünster again after a very short time. 
Table 2

Comparative table of composers included in the Parnassus Musicus Ferdinandaeus (1615) and in the Kremsmünster manuscript L76

\begin{tabular}{|c|c|}
\hline Parnassus (1615) & Ms L76 (1625) \\
\hline \multicolumn{2}{|l|}{ Arnoni, G. } \\
\hline \multicolumn{2}{|l|}{ Ballestra, $R^{*}$} \\
\hline \multicolumn{2}{|l|}{ Barbarini, B. } \\
\hline \multirow[t]{2}{*}{ Biumi, I. } & Biumi, I. \\
\hline & Bollius, I. F. \\
\hline \multicolumn{2}{|l|}{ Bontempo, A. } \\
\hline \multicolumn{2}{|l|}{ Borgo, C. } \\
\hline \multicolumn{2}{|l|}{ Brignoli, I. } \\
\hline \multicolumn{2}{|l|}{ Caccini, G. } \\
\hline \multicolumn{2}{|l|}{ Camanedo, F. } \\
\hline \multicolumn{2}{|l|}{ Casati, F. } \\
\hline \multicolumn{2}{|l|}{ Cavaccio, G. } \\
\hline & Cifra, A. \\
\hline \multicolumn{2}{|l|}{ Cima, A. } \\
\hline \multicolumn{2}{|l|}{ Cocciola, G. B. } \\
\hline Coda, F. & Coda, F. \\
\hline \multicolumn{2}{|l|}{ Coradini } \\
\hline \multicolumn{2}{|l|}{ Gabutio, G. C. } \\
\hline \multicolumn{2}{|l|}{ Ghizzolo, G. } \\
\hline Monteverdi, C. & Monteverdi, C. \\
\hline \multicolumn{2}{|l|}{ Mutis, B. Conte di Cesana } \\
\hline \multicolumn{2}{|l|}{ Nanterni, H. } \\
\hline \multicolumn{2}{|l|}{ Osculati, G. } \\
\hline \multicolumn{2}{|l|}{ Pasti, G. } \\
\hline \multicolumn{2}{|l|}{ Pelegrini, V. } \\
\hline \multicolumn{2}{|l|}{ Poss, $G$. } \\
\hline Priuli, $G$. & Priuli, G. \\
\hline \multicolumn{2}{|l|}{ Re, B. } \\
\hline \multicolumn{2}{|l|}{ Rizzi, M.A. } \\
\hline \multicolumn{2}{|l|}{ Rognoni, D. } \\
\hline \multicolumn{2}{|l|}{ Sansoni, $G$. } \\
\hline & Scaleta, 0 \\
\hline \multicolumn{2}{|l|}{ Sirena, G. } \\
\hline \multicolumn{2}{|l|}{ Tadei, $A$. } \\
\hline Turini, F. & Turini, F. \\
\hline \multicolumn{2}{|l|}{ Valentini, $G$. } \\
\hline & Viadana, L. \\
\hline
\end{tabular}

* Graz Court musicians are set in italic. 


\section{Bibliography}

\section{EARLY PRINTS}

Bonometti, Giovanni Battista, ed. Parnassus musicus Ferdinandaeus. Venice: Giacomo Vincenti, 1615. RISM $1615^{13}$.

Lomazzo, Filippo, ed. Flores praestantissimorum virorum. Milan: Filippo Lomazzo, 1626. RISM $1626^{5}$.

\section{LITERATURE}

Federhofer, Hellmut. “Alessandro Tadei, a Pupil of Giovanni Gabrieli”. Musica disciplina 6 (1952): 115-131.

___ _ "Graz Court Musicians and their Contributions to the Parnassus Musicus Ferdinandaeus (1615)”. Musica disciplina 9 (1955): 167-244.

___. Musikpflege und Musiker am Grazer Habsburgerhof der Erzherzöge Karl und Ferdinand von Innerösterreich (1564-1619). Mainz: B. Schott's Söhne, 1967.

Flotzinger, Rudolf. Eine Quelle italienischer Frühmonodie in Österreich. Veröffentlichungen der Kommission für Musikforschung, 6. Vienna: Böhlau in Kommissionsverlag der Österreichische Akademie der Wissenschaften, 1966.

. "Die kirchliche Monodie um die Wende des 16./17. Jahrhunderts". In Geschichte des katholischen Kirchenmusik, vol. 2, edited by Karl Gustav Fellerer, 78-87. Kassel: Bärenreiter, 1976.

____ "Die Lautentabulaturen des Stiftes Kremsmünster. Mit musikgeschichtlicher Auswertung der Handschriften L64 und L81 sowie thematischem Katalog des Gesamtbestandes”. PhD diss., Universität Wien, 1964.

___ Die Lautentabulaturen des Stiftes Kremsmünster. Thematischer Katalog. Tabulae musicae Austriacae, 2. Wien: Böhlau in Kommission, 1965.

Kellner, Altman. Musikgeschichte des Stiftes Kremsmünster: Nach den Quellen dargestellt. Kassel: Bärenreiter, 1956.

- "P. Benedikt Lechler: Seine Tätigkeit als Komponist und Leiter der Stiftsmusik von Kremsmünster”. PhD diss., Universität Wien, 1931.

___ Profeßbuch des Stiftes Kremsmünster. Klagenfurt: Carinthia, 1968.

Kirwan, A. Lindsey, and Gregory S. Johnston. "Bollius, Daniel". In The New Grove Dictionary of Music and Musicians, 2nd ed., edited by Stanley Sadie, 3:830-831. London: Macmillan, 2001.

Navach, Lisa. "Diruta, Girolamo". In Die Musik in Geschichte und Gegenwart, 2nd ed., edited by Ludwig Finscher, Personnenteil, 5:1089-1092. Kassel: Bärenreiter; Stuttgart: Metzler, 2001.

Saunders, Steven. Cross, Sword, and Lyre: Sacred Music at the Imperial Court of Ferdinand II of Habsburg (1619-1637). Oxford: Clarendon Press, 1995.

Suppan, Wolfgang. "Jelich (Jelić, Jelik, Jelitschitsch), Vincenz (Vinko)". In Steirisches Musiklexikon, 2nd ed., 322-323. Graz: Akademische Druck- und Verlagsanstalt, 2009. _. "Mutis, Bartolomeo Conte di Cesana". In Steirisches Musiklexikon, 2nd ed., 481. Graz: Akademische Druck- und Verlagsanstalt, 2009. 
. "Pfendner, Heinrich". In Steirisches Musiklexikon, 2nd ed., 517. Graz: Akademische Druck- und Verlagsanstalt, 2009

\section{MONASTIČNA VZPOREDNICA ZBIRKI PARNASSUS MUSICUS FERDINANDAEUS}

\section{Povzetek}

Sodobno glasbeno zgodovinopisje, ki preučuje predmet opazovanja v najrazličnejših okoljih in povezavah, v zbirki Parnassus musicus Ferdinandaeus (1615) najde vrsto zanimivih dejstev o kulturnih transferjih v začetku 17. stoletja, ki so bolj ali manj že znane in raziskane. Prispevek s tem bolj znanim glasbenim tiskom primerja malo manj znan rokopis s sorodnim glasbenim repertoarjem, ki je okoli leta 1625 nastal za praktično uporabo menihov benediktinskega samostana v avstrijskem Kremsmünstru (danes v A-KR pod signaturo L76). Ta je bil sicer že deležen obravnave v avtorjevem prispevku iz leta 1966 (Eine Quelle italienischer Frühmonodie in Österreich). Gre za zbirko 39 motetov s continuom, ki jih je zapisal en sam prepisovalec, verjetno italijanskega izvora, okoli leta 1625, v času, ko je bil tamkajšnji regens chori p. Wolfgang Christian (um. 1625). Ni izključeno, da bi rokopis iz Italije prinesel njegov sobrat in naslednik Benedikt Lechler (um. 1659), ki je verjetno osebno poznal vsaj skladatelje graškega in dunajskega kroga, imena, ki se pojavljajo v obeh primerjanih zbirkah. Alessandro Tadei je bil pol leta $(1628 / 29)$ tudi osebno angažiran v Kremsmünstru in bi lahko tudi sam prinesel rokopis v samostan. Ker sta bila tako posvetni dvor kot tudi cerkveno središče, kot je bil samostan v Kremsmünstru, zainteresirana za najsodobnejši glasbeni repertoar, pa najsi je šlo za prevzemanje povsem posvetnega monodičnega sloga tedaj nove glasbenodramatske glasbe ali pa novega cerkvenega sloga s podobnimi glasbenimi značilnostmi, sorodnost med obema zbirkama ne preseneča. Predstavljene so paralele - sorodnosti in razlike - med mrežo družinskih povezav notranjeavstrijskega dvora in dvornih glasbenikov, pomembna za nastanek, vsebino in odmevnost antologije Parnassus, in mrežo cerkvenih osebnih poznanstev med domačimi in italijanskimi glasbeniki za rokopis L76. 